\title{
CIVIL SOCIETY ORGANIZATIONS AND CONDITIONAL CASH TRANSFERS PROGRAMS IN LATIN AMERICA: THE CASE OF OPORTUNIDADES IN MEXICO
}

\section{Resumen}

María Isabel Blanco Velasco * Paulina Martínez González **

Este ensayo explora las percepciones que las organizaciones de la sociedad civil tienen del principal programa para combatir la pobreza en México: Progresa-Oportunidades (Prop), particularmente con respecto a los mecanismos del programa para fomentar participación y construir ciudadanía. Con base en entrevistas aplicadas a representantes de 42 organizaciones de la sociedad civil que trabajan en comunidades pobres en diferentes partes del país, las autoras observan que estas organizaciones son generalmente muy críticas del Prop; consideran que la participación de los beneficiarios es pasiva y no se orienta hacia la creación de la responsabilidad cívica. Más aún, la propia participación de estas organizaciones ha sido mínima. No obstante, la sociedad civil tiene un papel importante que jugar, argumentan las autoras, en prevenir que el programa se utilice para propósitos clientelistas, sobre todo con respecto al proselitismo electoral.

Palabras clave: Oportunidades, programas de transferencia monetaria condicionada, organizaciones de la sociedad civil, participación, ciudadanía.

*Profesora-investigadora del Centro Universitario de Ciencias Sociales y Humanidades de la Universidad de Guadalajara.

**Profesora-investigadora del Centro Universitario de La Ciénega de la Universidad de Guadalajara. Contacto: paulinamartinez@hotmail.com 


\section{Abstract}

This paper explores the perceptions of civil society organizations vis-à-vis Mexico's main anti-poverty program: Progresa-Oportunidades (Prop), particularly with regards to the program's mechanisms for fostering participation and building citizenship. Based on interviews with representatives from 42 civil society organizations that work in poor communities in different parts of the country, the authors observe that these organizations are generally quite critical of Prop; they see the beneficiaries' participation as passive and not geared towards creating a sense of civic responsibility. What is more, the participation of civil society organizations has itself been minimal. Nevertheless, civil society has an important role to play, the authors argue, in preventing the program from being used for clientelistic purposes, especially with regards to electoral proselytism.

Keywords: Oportunidades, Conditional cash transfer programs, civil society organizations, participation, citizenship. 


\section{INTRODUCTION}

7 here is an ongoing debate regarding the role of conditional cash transfers (CCT) in social policy. According to a World Bank report (Fizbein and Schady, 2009) there are 28 countries in the world that have adopted CCT programs. In Latin America, these programs began in Honduras and Brazil; Mexico followed with its national-level program in 1997. By 2007, 16 Latin American countries had CCT programs (Valencia, 2008). Even though in the cases of Argentina, Brazil and Mexico, the programs' design was largely autochthonous, the interest in promoting them in the region has come from international financial institutions. The IADB provided 4.5 billion dollars to support CCT programs in the period from 2000 to 2005, during which time they multiplied quickly throughout the region. In Latin America and the Caribbean, these programs reach over 20 million families, which amounts to 70 million people. In other words, in just a decade they have reached $12 \%$ of the estimated population of the region (ibidem).

Mexico's program Progresa-Oportunidades (Prop) was the first CCT program to be implemented on a massive scale. Originally called "the Program for Education, Health and Food" (Programa de Educación, Salud y Alimentación - Progresa) when it was initiated in 1997, it has the distinction of being the most evaluated CCT program in the world, and according to the World Bank, it has become an exemplary global point of reference:

Mexico's Oportunidades is one of the iconic cases. The program started early, its evolution has been carried out thoughtfully, and it has been successful. What really makes Mexico's program iconic are the successive waves of data collected to evaluate its impact, the placement of those data in the public domain, and the resulting hundreds of papers and thousands of references that such dissemination has generated (Fizbein and Schady, 2009: 6). 
Prop's general objective is: "To contribute to breaking the intergenerational cycle of extreme poverty by favoring the development of the educational, health and nutritional capacities of the families receiving benefits from the Program" (Sedesol, 2008). The program consists of providing aid in the form of direct money transfers to families living in conditions of poverty, so that these resources can be used to pay for health expenses and and to cover the cost of schooling for children and youth, from the primary level to high school. It is also hoped that the resources provided by the program will have a positive effect on the quality and quantity of the food consumed by the poor. Along these lines, one of the Program's conditions is that mothers and minors receiving benefits must pay regular visits to health clinics in their locality in order to receive counseling on the subjects of health and medical attention. In addition, mothers must ensure that their children attend school regularly. These are just two of the so-called "co-responsibilities".

In general, Prop seeks to mitigate poverty, primarily through an increase in formal levels of education, improved diets and better health, so that 'graduates' of the program have a better chance of successfully inserting themselves into the labour market. Cash transfers are given directly to mothers in order to encourage women to play a leadership role in fostering family and community development. Many prominent researchers (for example, Cohen and Franco, 2006) argue that this program has made important contributions to public policy for fighting poverty, while acknowledging the challenges that still lie ahead in terms of converting the program into a catalyst for fostering participation in integral development projects. In this vein, the main objective of our study is to investigate the forms of participation and citizenship promoted by Prop. In particular, we are interested in the opinions expressed by representatives of civil society organizations.

Our analysis proceeds as follows: first we discuss participation in social programs on a theoretical level, mentioning the mechanisms associated with Prop that supposedly foster participation 
and a sense of citizenship. From there, we outline the methodology we used to select 42 civil society organizations that operate in different parts of the country, in order to garner their opinions regarding the nexus between participation and citizenship, on the one hand, and Oportunidades on the other. The next section summarizes the results of this research. As we shall see, although there are many nuances, organized civil society in Mexico is generally quite critical of Prop; the representatives interviewed consider that it does not allow for significant forms of participation nor does it foster the growth of citizenship. What is more, while most civil society organizations in Mexico envisage the possibility of collaborating with the government in order to combat poverty, so far there has been little collaboration. In the final section, we reflect on this situation, suggesting that organized civil society has an important role to play as watchdogs in order to prevent political parties from using the program for clientelistic purposes.

\section{PARTICIPATION AND CITIZENSHIP IN SOCIAL PROGRAMS}

We believe, like Cunill (2004), that it is necessary to provide incentives to promote the autonomous organization of society in order to construct mutual responsibility between the State and society for the production of social services, on the assumption that citizen participation in public policy will in turn contribute to the construction of citizenship. In addition to social policies' potential for strengthening citizen participation and thereby providing a civic education, there is a permanent risk, heightened at times of elections, that social programs be used for purposes of clientelism. In Mexico, a number of mechanisms have been designed to counter this danger, including: monitoring by citizens, social audits, and electoral observation. These measures help ensure a certain level of accountability for which there can be no substitute if democracy is to advance.

Hevia (2007) points to three concrete experiences of civil-society auditing in Mexico: first, the 20 indigenous radio stations 
managed by the Commission for Indigenous Peoples' Development (Comisión para el Desarrollo de los Pueblos Indígenas - CDI), which broadcast in 31 native languages, with a potential audience of 6 million people; second, the Support Programs for Agricultural Day Laborers (Programas de Apoyo a los Jornaleros Agrícolas); and third, Oportunidades. The author concentrates on the last of these, suggesting that it is the most important program in Mexico for combating poverty, taking into consideration its coverage (it operates in every municipality in the country) and the size of its budget (63.1 billion pesos en 2010).

The Citizens' Service System (Sistema de Atención Ciudadana del Programa Oportunidades) has been created in Mexico to provide information about Oportunidades and to receive requests, complaints or accusations regarding the program. This system is operated within the same administrative framework as Prop and is obliged to pass on complaints to the Special Prosecutor's Office for Electoral Offenses (Fiscalía Especializada para la Atención de Delitos Electorales -FEPADE). One of the most serious charges registered through this system has to do with clientelism, in particular, using the program to get beneficiaries to turn up to political events or to vote for a certain political party, usually the one in power. This is done, for example, by promising to extend benefits to those who attend a certain political meeting or, inversely, by threatening to curtail the benefits of those who fail to attend (Hevia, 2007: 30). The number of accusations of political proselytism received between the last six months of 2004 and the first six months of 2005 was 225. In 81\% of these cases, the people who represent Prop on the local level -namely committee members known as vocales, liaison officers called enlaces, and municipal authorities - were singled out as the perpetrators (ibid). This information is consistent with the findings of another research project denouncing direct use of the programs for political ends by municipal authorities (Alianza Cívica, 2006: 7).

Hevia (2007) tell us that half of the charges were sent to FEPADE, the authority responsible for investigating this kind of offence. According to the follow-ups that the author was able to 
make, accusations of proselytism have little chance of leading to sanctions, which leads the writer to ask where the legitimacy of civil-society auditing resides. Not in its representativeness, since there is legislation that grants this power to citizens (at least officially). Nor in its autonomy, because, most of the time, governments are obliged to create some sort of mechanisms to foster transparency, even if citizens do not organize themselves around demands for accountability. Its legitimacy, the author concludes, must lie in its effectiveness in providing civil society to act as a counterweight to the State. Otherwise, civil-society auditing only amounts to an exercise whereby citizens, without any real whistle-blowing powers, provide legitimacy to governments that claim to be transparent and participative.

Based on a study of citizens' participation in 18 anti-poverty programs in Argentina, Chile, Paraguay and Peru, Irarrázabal (2005) proposes five prototypes found in relationships between beneficiaries and governmental organizations:

- A model without participative features, which is the traditional scheme for delivering social services, whereby the government defines every step of the process, and the beneficiaries can only choose to accept or refuse the service;

- A dual model that includes a traditional non-participatory program and a parallel one that does involve some degree of participation, giving beneficiaries the option to sign up for the latter;

- A program that is traditional in most respects, but that obliges beneficiaries to participate in actions of co-responsibility;

- A program that includes participation at one stage of the program's cycle (for example, its design or evaluation), thereby allowing citizens to participate in deciding how the service is to be delivered, but not in defining the responsibilities of beneficiaries, and

- A highly participatory model that includes a consultative committee made up of representatives of those receiving benefits, of the government and of civil society organizations, giving these actors the opportunity to intervene at different stages of the program's 
design, application and evaluation. Irarrázabal observes that, even in programs that lean towards this highly participatory model, allowing for citizens to participate in defining or modifying the beneficiaries' corresponding tasks, citizens' participation has not led to any significant modifications in this regard (2005: 30).

In this light, it is not surprising that the concept of participation has become a central topic of discussion in the context of CCT programs. The mutual distrust between the State and civil-society organizations continues even where there is dialogue and some degree of participation, as noted by Ramírez Sáiz (2006). As regards to top-down initiatives, the creation of some sort of "consultative committee" tends to be viewed as the most advanced and promising. However there is always the risk of exhaustion and frustration and this shows up in evaluations made by representatives of civil society that participate in consultative committees and by social movements in general (see for example, Dagnino, 2006; Isunza and Olvera, 2006, and Peralta, 2008).

\section{PARTICIPATION IN PROP ANTECEDENTS AND METHODOLOGICAL CONSIDERATIONS}

On the basis of what has been said above, we believe that the evaluations of Prop that have been carried out to date do not pay enough attention to the perceptions of other actors, specifically non-governmental organizations, more commonly known in Mexico as "civil society organizations" (CSOs). On this account, it is important to mention certain antecedents. First, in 2001, just before the program's name was changed from Progresa to Oportunidades, with a concomitant expansion in its coverage from rural areas to include urbanized settings, a project was initiated with the support of eleven CSOs: the Inter-Institutional Strategy for Training in Progresa Localities (see Valencia, 2006). Second, according to the United Nations Development Programme (UNDP, 2007), Prop has incorporated a "Program for Encouraging Civil Society Organizations", 
supposedly to foster the participation of CSOs in overseeing the functioning of the program. Another interesting effort is a study of the convergence between the resources channeled through Oportunidades and the aid provided by the other social programs that are run by different governmental agencies or by civil society organizations. This study (Torres, 2006) observes certain synergies in the reconstruction of seven experiences that involve collaboration between CSOs, the administrators of Prop and governmental agencies that manage other social programs. According to the author, the principal achievements of this synergy include, not just the multiple and overlapping benefits received by the beneficiaries, but also the construction of citizenship and the knowledge gained through these experiences.

All the same, no systematic studies have been undertaken to assess the perceptions of CSOs that operate in the same local settings as Prop. To enquire into the points of view of these actors is the main interest of this research paper. In particular, we explore the perceptions and proposals of CSOs regarding the kind of social participation and the type of citizenship encouraged by Oportunidades.

In order to select a sample of CSOs, we considered four criteria: the CSO's objectives, its legal status and years of experience, geographical representation and types of CSO. With regards to the first, we looked for CSOs that focus their attention on issues related to nutrition, education and health, that is, the three components of Prop. Second, we limited our research to organizations that are legally constituted and have been working for at least five years. In order to identify these CSOs we reviewed the directories of several national and regional organizations, including Centro Mexicano de Filantropía, Convergencia de Organismos Civiles para la Democracia and Fundación Empresarial de Chihuahua. In addition we contacted people with key connections in different parts of the country. With regards to the geographical criterion, the selection procedure started from the idea of covering at least one state in each meso-region indicated in the National Development Plan 2001-2006, these being South-Southeast (SSE), Central West 
(CW), Central (C), Northeast (NE) and Northwest (NW). Due to limitations in time and resources, the NW region is the only one that ended up not being covered. On this basis, we chose eight states (of the 32 in the country) with a significant number of families that receive benefits from Prop (about half of all those in the country covered by the program), and with considerable CSO presence. On the micro-level, within these states we looked for CSOs that operate in zones with a high concentration of families living in conditions of extreme poverty. Finally, with regards to "types" of CSOs, we sought representation across the tripartite typology proposed by Olvera (2001), which includes: a) organizations that promote development and the creation of cultural groups and movements; b) private aid associations, and c) human rights organizations. In all, we interviewed representatives from 42 organizations. Table 1 summarizes the characteristics of these organizations and Table 2 indicates their geographical representation.

TABLE 1

Characteristics of selected CSOs

\begin{tabular}{lc}
\hline \multicolumn{1}{c}{ TYPE OF CSO } & $\begin{array}{c}\text { NUMBER } \\
\text { SELECTED }\end{array}$ \\
\hline $\begin{array}{l}\text { Organizations that promote development and the } \\
\text { creation of cultural groups and movements }\end{array}$ & 20 \\
$\begin{array}{l}\text { Private aid associations (14) and foundations (3). } \\
\text { Associations and social movements for the defense of } \\
\text { human rights. }\end{array}$ & 17 \\
Network of organizations & 7 \\
\hline TOTAL & 42 \\
\hline
\end{tabular}

We interviewed 48 people from these organizations: 23 men and 25 women. The interviews were conducted between the end of 2002 and the beginning of 2003 and formed part of a larger research project about social policies that also included the perceptions of business people. ${ }^{1}$ The methodological strategy, basically

1. This research project is entitled "Nuevos actores sociales en la política social. Organi- 
of a qualitative nature, sought to identify the perceptions of civil society organizations expressed in 42 semi-structured interviews. Questions revolved around the following three themes: the ideal form of social participation for CSOs, the concept of "citizenship", and future expectations regarding how CSOs interact with Prop.

TABLE 2

Number of CSOs per state

\begin{tabular}{|c|c|}
\hline StATE & $\begin{array}{c}\text { Number of } \\
\text { CSOS }\end{array}$ \\
\hline Chiapas & 6 \\
\hline Oахаса & 7 \\
\hline Veracruz & 7 \\
\hline Jalisco & 6 \\
\hline Michoacán & 5 \\
\hline Estado de México & 1 \\
\hline Distrito Federal & 4 \\
\hline Chihuahua & 7 \\
\hline TOTAL & 42 \\
\hline
\end{tabular}

\section{CSO PERCEPTIONS OF PROP}

The majority of those interviewed (over two thirds) felt that Prop is a program with insufficient participation on the part of beneficiaries. Half the critics of the Program consider that the beneficiaries' participation is passive or imposed. About a quarter agree with the way that beneficiaries participate and the rest do not know anything about it. Others observe that the program does not take into account the specificities of local populations; it does not start with a self-diagnosis of their needs and potentials, nor does it involve them in the design of the program. From this

zaciones Civiles y Empresarios ante el Programa Oportunidades 2002-2004", coordinated by E. Valencia and C. De Alba. 
perspective, Prop does not generate conscientious participation. According to one of the interviewees, representing a gender and development organization in San Cristóbal de Las Casas, Chiapas: "People only go to the talks because they have to, they only go to the check-ups because they have to (...) they participate because they know they will get an economic benefit, but not because they are conscience of the importance of participation".

Another respondent, also a member of a gender and development organization, but in this case in the state of Chihuahua, opines:

They do not believe that it is a program that will really give them opportunities, no. People I know, I have asked them, 'what is it?', and they say, 'well, what happens is they bring us money, but in exchange we have to do these things'. There should be more information provided to the people receiving benefits, in order to explain why it is being given, so there is real co-responsibility. [Otherwise] it's just doing what the doctor tells you to do, or what teachers say you should do.

Similarly, a member of a development organization in the state of Jalisco had this to say about the beneficiaries' participation:

Beneficiaries do not participate properly in the program. I don't believe they can, because they are tools; government bodies do what they want and not what the beneficiaries themselves really need to be done: to organize themselves, form themselves into groups. There's still a lot to do, [for example] transfer a large amount of decision-making power to the communities themselves regarding who to include and who not to, as beneficiaries of the program.

We also detected some opinions to the effect that the program does not resolve the underlying problems of poverty, because it works as a palliative that encourages paternalism and only resolves immediate needs. To this effect, a CSO worker in the state of Jalisco stated the following: 
There's a paternalistic attitude, like, 'they have to give it to us' ... people get involved because, well, it's money, or because they have medical needs that are urgent. But to say that they identify with the program or that they feel some sort of commitment, that I would doubt.

From a different angle, some of the interviewees believe that Prop does not take into account the structure or forms of community-based organizations, nor the cultural differences between one community and another. Accordingly, many beneficiaries are unaware of the program's aims. This was illustrated in an interview with a member of peasants' rights organization in the state of Chihuahua:

For the indigenous zone, there ought to be a completely different focus, and this focus should be decided jointly with the indigenous communities... [with regards to] health questions, indigenous people have their traditional forms of healthcare, so how do we recover this local knowledge? On the subject of education, so maybe they won't go to a conventional school, but they have their own ways of educating in their communities, and this should be encouraged.

The great majority of CSO representatives interviewed conveyed the perception that Prop does not encourage the creation of citizenship. Ten percent of those interviewed stated that it does create or can create citizenship. Only one person gave a definite "yes"; the others communicated doubts as to whether the program can create citizenship. Most of those who talked about the relation of citizenship to rights in detail said the program did not raise consciousness regarding citizens' rights. Among the reasons given by those interviewed for this omission, we heard that the Program generates passive attitudes, that it is coercive (conditional) and that it does not teach beneficiaries what citizenship is, nor does it promote reflection and critical thinking. As one member of a human-rights organization in the state of Oaxaca said: 
No. I do not believe [that it creates citizenship], that's a long way off. The Program would have to be really focused on that, [but] no mechanism exists, not even ... in the meetings, which are not participative, in fact quite the opposite, the women attending them are very dependent, very tired, forced to be there, so there is no willingness, even among those receiving benefits, to learn more and take the training courses.

This is corroborated by a representative of a development organization in Mexico City who sees that, "what it creates is an image in the beneficiary of a passive subject receiving aid, which I believe is quite contrary to a citizen insisting on his rights, exercising his rights".

To be fair, it is important to mention that some representatives of CSOs observed positive changes in the situation of those receiving benefits. For example, one member of a CSO geared towards fostering community development in Tapalpa, Jalisco, observed: "I have seen many families receiving Oportunidades and they are better off, much better off, much much better off". Among its positive aspects, the people we interviewed recognized that the program's financial assistance is indeed useful for helping poor families meet their expenses and that women's roles have changed for the better on the family and community level, with the help of the money they receive and administer. In the words of one woman, a representative of a gender and development organization in Chihuahua: "It seems to me to be positive that the transfers are given principally to women, female heads of households, or even if they are not heads of the family, that they are given to women".

Diverse opinions were expressed as regards to whether CSOs should participate in public policies and in actions to overcome poverty jointly with governments. Two thirds of the people we interviewed stated it is possible and a number of proposals stand out, for example: bringing in the experience of CSOs, co-coordinating public funds for CSO-led projects, and creating legislation to allow CSOs to participate in the design of social programs. About one third of the respondents said that it is still hard to imagine 
joint actions. However, a large majority judged that CSOs could participate in Prop through the sharing of their experiences, by taking part in debates, by getting involved in the evaluation process, etc. What is more, some organizations have taken part in round-table discussions with the administrators of Prop, but consider that this work was never followed up. Seventeen of the organizations said they were ready to participate in specific actions related to the program, specifically:

- Facilitating the participation of the beneficiaries in the design and evaluation of Oportunidades;

- Participating themselves in the evaluation process and in dialogue geared towards reformulating the program;

- Collaborating in the diagnosis of the local population's needs, their problems and necessities;

- Providing feedback with regards to possible local development projects that may be linked to the program, and

- Giving instruction in the subjects that they are skilled in and that are linked to the program.

The following quote from a member of a CSO in Veracruz is illustrative of some of these points:

It can't be denied the Civil and Social Organizations are present in the region, they have experiences, they have an opinion, they have a history, a job that they have been doing for a number of years and they have the ability to take actions, to get involved, to say what can and what cannot be fixed. But obviously it comes from the people, in part - even if this is not recognized - and they will have to try to find a form that is much more effective, where people can give their opinions, where they can in fact give them from the design stage, and not just accept an invitation to see this or that, having to go on such and such a course, but in the design itself.

The people we interviewed mentioned that one of the advantages that CSOs have is that they are close to the people, that they work 
with the bases, know the dynamics of local power relationships and the problems that can be created by the program. They also know the strengths and the weaknesses of the local population, the ways they represent themselves, their language, their symbols. This is important especially in the context of cultural diversity that exists in Mexico.

In response to the question as to whether there might be a chance for CSOs to interact with the government in order to solve the problem of poverty, most of the organizations left the possibility open. However, three organizations said they were not willing to participate by virtue of the fact that they wished to keep their distance from the political manipulation that goes on through Prop. From this view, the government just offers palliatives and not structural solutions to the problem of poverty. These organizations see themselves as watchdogs:

Well it's as I said, we have to be careful not to take on the role of the government, it's really not our business, so maybe we have tried sometimes to see that the aid gets to the people, but really our role has been to denounce whatever it is that really goes on in the communities (Interview with a member of human rights organization in the State of Oaxaca).

In contrast, other respondents consider that their organizations and the government have the same objectives, but that they have not found the way collaborate. From this perspective, the problem is that the government does not take them into account; it does not recognize the resources that CSOs can offer.

\section{FINAL REMARKS}

In general, our research shows that CSOs are very critical of Prop. With regards to participation, the program is seen to be extremely narrow in practice. Beneficiaries do not participate directly in the design of the program, nor do they have the power to intervene in decisions that would allow them to have a say in 
the daily workings of the program. As such, we can conclude that participation in Prop corresponds to the third prototype proposed by Irarrázabal (2005) in the typology presented above. In this scheme, the supply of goods and services is fixed, and the beneficiaries cannot modify it, any more than they can change the actions required to join and stay in the program. The participation of the population is encouraged as long as it is restricted to the so-called co-responsibilities.

We found diverse and often contradictory opinions among CSOs regarding these co-responsibilities. Essentially, they are tasks that the beneficiaries of the program are required to perform in the areas of health and education in order to receive cash transfers. Here is where the debate opens: is conditioned monetary aid more effective than unconditional aid? Does it create incentives for sending children to school and keeping them there? Do obligatory visits to health centers help with the prevention of illness and improving the health of the beneficiaries? Our research discovered diverse and often conflicting opinions in the CSO sector regarding these questions. Some organizations consider co-responsabilities to be a good thing, since they discourage paternalism and passivity, while others consider them to be limiting, even unjust.

Although the CSO sector is generally very critical of Oportunidades, there is some recognition of the program's positive aspects, including improved health and nutrition and higher levels of formal education. Also, delivering CCT directly to women is generally seen as positive aspect of the program. This coincides with other research findings, for example Cohen and Franco (2006: 87), who insists that this strengthens and improves the position of women in the family.

We found that there has been little collaboration between CSOs and Prop. For a few of the CSO representatives interviewed, collaboration between their organizations and the government is simply impossible. Their view of what needs to be done to overcome poverty is radically different from that which is embodied 
in Prop. Accordingly, they focus on whistle blowing. On the other hand, the majority of the respondents suggested that some form of collaboration is possible. At the same time, these respondents expressed reservations and warned of risks.

Although there has been little collaboration to date, we believe that CSOs constitute an important social actor because of the autonomy they can exercise vis-à-vis the government and because of their ability to act as watchdogs on any electoral use of the program. In Mexico, the 2012 federal election is rapidly approaching and the temptations to use the program as a platform for proselytism are present. On this point, it is interesting to note that Prop's rules of operation recently changed regarding the designation of local committee members (vocales), who are themselves beneficiaries who represent their communities. Before 2008, they were elected by their fellow beneficiaries. Since then, they have been "elected by staff of the State Co-ordination as the only body with the faculty to accept or retain, as well as to replace or nominate spokespersons" (Sedesol, 2008: 15). In other words, the administrators of Prop now decide who will be a vocal. With these modifications there is now more room than ever for clientelism and political proselytism.

On this point, we concur with Hevia (2007) on the need to maintain and improve the information possessed by the program's beneficiaries, about their rights and duties, about how citizens' accusations work; and about the laws that prohibit using social programs for electoral purposes. From this view, the role of CSOs is crucial in preventing the clientelistic use of Oportunidades.

\section{REFERENCES}

Alianza Cívica (2006), Segundo Informe del Monitoreo de Programas Sociales. Junio 2006, México, Alianza Cívica.

CoHen, Ernesto y Rolando Franco (coords.) (2006), Transferencias con corresponsabilidad. Una mirada latinoamericana, México, FLACSO/ Sedesol. 
Cunill, Nuria (2004), "Balance de la participación ciudadana en las políticas sociales. Propuesta de un marco analítico" en A. Ziccardi (coord.) Participación ciudadana y políticas sociales en el ámbito local, México, Indesol. DAGnino, Evelina (2006), "Sociedad Civil, participación y ciudadanía: ¿De qué estamos hablando?” en E. Isunza y A. Olvera (coords.), Democratización, rendición de cuentas y sociedad civil: participación ciudadana y sociedad civil, México, CIESAS/ Universidad Veracruzana/ Cámara de Diputados/ Miguel Ángel Porrúa.

FizBEIn and Schady (2009), Conditional Cash Transfers, Reducing present and future poverty, A World Bank Policy Research Report, Washington, World Bank.

Hevia de la Jara, Felipe (2007), Contraloría Social y Protección de Programas Sociales, México, CIESAS/ PNUD.

IRARRÁZABAL, Ignacio (2005), “Participación ciudadana en programas de reducción de la pobreza en América Latina: experiencias en Argentina, Chile, Perú y Paraguay", Diálogo Regional de Política, Banco Interamericano de Desarrollo.

IsunzA Vera, Ernesto y Alberto J. Olvera (coords.) (2006), Democratización, rendición de cuentas y sociedad civil. Participación ciudadana y control social, México, CIESAS/ Universidad Veracruzana/ Cámara de Diputados/ Miguel Ángel Porrúa.

Olvera, Alberto (2001), Sociedad Civil, gobernabilidad democrática, espacios públicos y democratización: los contornos de un proyecto, México, IIHS/ Universidad Veracruzana.

(coord.) (2003), Sociedad Civil, esfera pública y democratización en

América Latina: México, México, Universidad Veracruzana/ Fondo de Cultura Económica.

PERAlta, Carlos (2008), Entre la democracia participativa y la cotidianidad democrática en Jalisco; interacciones entre gobierno panista y organizaciones civiles en juntas de gobierno y consejos consultivo, Tesis de doctorado en Ciencias Sociales, México, CIESAS.

RAmírez Sáiz, Juan Manuel (2006), “Las organizaciones cívicas en la democratización de la sociedad y del sistema político mexicanos, 19942000" en E. Isunza y A. Olvera (coords.), Democratización, rendición de cuentas y sociedad civil: participación ciudadana y control social, México, CIESAS/ Universidad Veracruzana/ Cámara de Diputados LIX Legislatura/ Miguel Ángel Porrúa. 
Secretaría de Desarrollo Social (Sedesol) (2008), Reglas de Operación del Programa de Desarrollo Humano Oportunidades, México, Sedesol.

Torres, Gabriel (coord.) (2006), Sinergias con Oportunidades. Experiencias de Organizaciones Civiles y programas de Gobierno, México, CIESAS/ Papeles de la Casa Chata.

United Nations Development Programme (UNDP) (2007), “Blindaje electoral y fortalecimiento de la Contraloría Social", Buenas prácticas en la protección de programas sociales, México, PNUD.

VAlencia, Enrique (2006), "Las evaluaciones del Progresa-Oportunidades, el caso de las Organizaciones de la Sociedad Civil" en G. Ordónez, R. Enriques, I. Román y E. Valencia (coords.), Alternancia, políticas sociales y desarrollo regional en México, Tijuana y Guadalajara, El Colegio de la Frontera Norte/ ITESO / Universidad de Guadalajara.

VAlEnCiA-Lomelí, Enrique (2008), “Conditional Cash Transfers as Social Policy in Latin America: An Assessment of their Contributions and Limitations", Annual Review of Sociology, no. 34, pp. 475-499. 